\title{
Hubungan Keaktifan Kader dan Partisipasi lbu pada Kegiatan Posyandu dengan Cakupan ASI Eksklusif di Wilayah Kerja Puskesmas Waru Sidoarjo
}

\author{
Relationship between Cadres Activity \& Mother's Participation to Posyandu \\ Activity with Exclusive Breastfeeding Coverage in Waru Sidoarjo Public Health \\ Center
}

Nisa Agestazhar Rhapsodia*1, Sri Andari², Sri Sumarmi ${ }^{3}$

\begin{abstract}
ABSTRAK
Latar Belakang: Program ASI eksklusif penting dikarenakan pemberian ASI merupakan tahap penting bagi tumbuh kembang bayi, akan tetapi cakupan ASI eksklusif masih rendah. Peran kader posyandu penting untuk meningkatkan cakupan ASI eksklusif dengan memberikan edukasi kepada peserta posyandu mengenai ASI eksklusif.

Tujuan: Mempelajari hubungan antara keaktifan kader dan partisipasi ibu dengan cakupan ASI eksklusif pada posyandu yang berada pada wilayah kerja puskesmas Waru Sidoarjo.

Metode: Jenis penelitian analitik dengan desain cross sectional dilaksanakan pada bulan Juli-September 2018. Besar sampel 51 posyandu dipilih secara acak dengan metode stratified random sampling. Variabel penelitian adalah cakupan ASI eksklusif, pelaksanaan kegiatan posyandu, tingkat keaktifan kader dan partisipasi ibu balita diperoleh dari data sekunder posyandu yang berada di wilayah Waru. Untuk memperkuat hasil dilakukan FGD (Focus Group Discussion) dengan ibu balita di 5 posyandu yang dipilih secara acak. Analisis menggunakan Spearmen test.

Hasil: Dari 51 posyandu tidak ada cakupan ASI eksklusif yang memenuhi target sebesar 80\%. Target cakupan D/S adalah $87 \%$, sebesar 44 posyandu (86,27\%) tidak memenuhi target sedangkan 7 posyandu (13,73\%) telah memenuhi target. Semua kader termasuk kategori kader aktif. Kegiatan posyandu yang berjalan secara rutin sebesar $83,31 \%$ sedangkan sebesar 15,69\% tidak rutin. Tidak ditemukan hubungan antara partisipasi ibu balita $(p=0,077)$ dan keaktifan kader $(p=0,691)$ dengan cakupan ASI eksklusif pada kegiatan posyandu. Ada hubungan kegiatan posyandu dengan cakupan ASI eksklusif ( $p=$ 0,004 ). Dari FGD didapatkan hasil yang mempengaruhi cakupan ASI eksklusif adalah pengetahuan, pemberian susu formula dan ibu yang bekerja.

Kesimpulan: Partisipasi ibu dan keaktifan kader posyandu tidak berhubungan dengan cakupan ASI eksklusif, namun kegiatan posyandu berhubungan dengan cakupan ASI eksklusif. Hasil FGD didapatkan faktor-faktor yang mempengaruhi cakupan ASI eksklusif adalah pengetahuan, pemberian susu formula dan ibu yang bekerja. Perlu ditingkatkan pelaksanaan kegiatan posyandu dan sosialisasi pada peserta posyandu.
\end{abstract}

Kata Kunci: ASI Eksklusif, kader, Posyandu

\section{ABSTRACT}

Background: Exclusive breastfeeding program is important because breastfeeding is an important stage for baby's growth. However, exclusive breastfeeding coverage is still low. The role of posyandu cadres is important to increase the coverage of exclusive breastfeeding by giving education to posyandu participants about exclusive breastfeeding.

Objective: To study the relationship between cadre activeness and mother's participation with the coverage of exclusive breastfeeding at the posyandu located in the work area of Waru Public Health Center, Sidoarjo.

Methods: Analytic research with cross sectional design was carried out in July-September 2018. The sample size of 51 posyandu was randomly selected using the stratified random sampling method. The research variables were exclusive breastfeeding coverage, the implementation of posyandu activities, the level of activity of cadres and the participation of mother of children under five were obtained from secondary data posyandu. The location was in the Waru region. To strengthen the results, FGD (Focus Group Discussion) was conducted with mothers of children under five in 5 randomly selected posyandu. Analysis used the Spearmen test.

Results: Out of 51 posyandu there was no exclusive breastfeeding coverage that meets the target of $80 \%$. The target D/S coverage was $87 \%, 44$ posyandu (86.27\%) did not meet the target while 7 posyandu (13.73\%) had met the target. All cadres belong to the category of active cadres. Posyandu activities that run routinely were $83.31 \%$ while $15.69 \%$ were not routine. No relationship was found between mother's participation in infants $(p=0.077)$ and cadre activeness $(p=0.691)$ with exclusive breastfeeding coverage at posyandu activities. There was a relationship between Posyandu activities and exclusive 
breastfeeding coverage $(p=0.004)$. From the FGD, the results that affect the coverage of exclusive breastfeeding were knowledge, formula feeding and working mothers.

Conclusion: Mother's participation and activeness of posyandu cadres are not related to exclusive breastfeeding coverage, but posyandu activities are connected with exclusive breastfeeding coverage. From the FGD results, it is found that the factors that influenced the exclusive breastfeeding coverage are knowledge, formula feeding and working mothers. It needs to increase the implementation of posyandu activities and socialization for posyandu participants.

Keywords: Exclusive breastfeeding, cadres, Posyandu

*Koresponden

agestazhar@gmail.com

1,3Departemen Gizi Kesehatan, Fakultas Kesehatan Masyarakat - Universitas Airlangga,

Kampus C Mulyorejo, 60115, Surabaya, Jawa Timur, Indonesia

${ }^{2}$ Dinas Kesehatan Kabupaten Sidoarjo, Jl. Mayjend Sungkono 46, Sidoarjo, Jawa Timur, Indonesia

\section{PENDAHULUAN}

Tahun 2011 data dari WHO dan UNICEF tentang laporan anak dunia menunjukan angka 136,7 juta bayi yang lahir di dunia hanya 32,6 juta yang mendapat ASI eksklusif selama 6 bulan masa kehidupan pertamanya ${ }^{1}$. Menurut profil kesehatan Indonesia pada tahun 2014 cakupan ASI eklsusif adalah sebesar $55 \%$ meskipun nilai tersebut mengalami peningkatan dari tahun sebelumnya namun masih belum mencapai target nasional yaitu $80 \%$ 2. Cakupan ASI eksklusif 4-5 bulan di daerah perkotaan antara $4 \%-12 \%$, sedangkan untuk di pedesaan $4 \%-25 \%$. Pencapaian cakupan ASI eksklusif 5-6 bulan di perkotaan antara $1 \%-13 \%$ sedangkan di pedesaan $2 \%-12 \%{ }^{3}$. Tahun 2014 wilayah Kabupaten Sidoarjo memiliki angka cakupan ASI eksklusif 54,5\%. Sebanyak 12,574 anak mendapat ASI esklusif dari 24,920 jumlah anak, namun cakupan tersebut masih belum memenuhi target ${ }^{4}$. Tahun 2017 Cakupan ASI eklsusif di wilayah Kabupaten Sidoarjo sebesar 69,1\%. Cakupan ASI eklsusif paling tinggi adalah pada puskesmas Tulangan sebesar $87,0 \%$ dan Cakupan ASI paling rendah adalah puskesmas Waru sebesar $49.8 \%{ }^{5}$. Untuk cakupan D/S memiliki angka $66,37 \%$ dan masih belum memenuhi target sebesar $87 \%$ 5.

Air Susu Ibu (ASI) sangat bermanfaat untuk bayi, namun juga bermanfaat untuk ibu, beberapa manfaat ASI untuk ibu dan anak diantaranya tidak perlu mengeluarkan uang untuk makanan tambahan atau makanan anak karena pemberian ASI tersebut gratis sehingga dapat menghemat anggaran keluarga, zat gizi yang terkandung dalam ASI membuat anak dapat tumbuh dan berkembang secara sempurna, ASI juga dapat meningkatkan kekebalan tubuh bayi sehingga dapat mengurangi risiko terkena virus dan penyakit, ASI membantu memperkuat ikatan emosional ibu dan anaknya sehingga akan terjalin kedekatan, pemberian ASI dapat mengurangi tingkat depresi pada ibu, ASI mengurasi risiko obesitas dan manfaat-manfaat ASI yang lainya 6,7 .

Pemberian ASI eksklusif untuk bayi juga sudah dijelaskan dalam peraturan pemerintah, diterbitkanya Peraturan Pemerintah No. 33 Tahun 2012 mengenai ASI eksklusif menjadi bukti nyata pentingnya pemberian ASI, 7 hal pokok yang diatur dalam PP tersebut adalah tanggung jawab pemerintah daerah Provinsi, Kabupaten maupun Kota. 7 hal pokok tersebut adalah tentang ASI, penggunaan susu formula dan produk lainya, tempat kerja sarana umum, dukungan dari masyarakat, pendanaan, pembinaan dan pengawasan, sehingga program pemberian ASI eksklusif merupakan prioritas untuk dijalankan oleh pemerintah ${ }^{8,9}$. Implementasi program ASI eksklusif dapat didapatkan pada program posyandu terutama mengenai edukasi mengenai ASI eksklusif 10,11. Posyandu adalah Upaya Kesehatan Bersumberdaya Masyarakat (UKBM) yang dilaksanakan dan dikelola dari, oleh, untuk dan bersama masyarakat sehingga semua ikut andil dalam memperoleh pelayanan kesehatan dasar bagi ibu, bayi dan balita ${ }^{12,13}$. Dalam pelayanan posyandu terdapat pelayanan sistim lima meja, meja pertama ada pendaftaran, kedua adalah penimbangan, ketiga adalah pengisian KMS, keempat adalah penyuluhan dan meja terakhir adalah pemberian tindakan oleh tenaga kesehatan yang berwenang. Pelayanan pada meja 4 secara tidak langsung berkaitan dengan implementasi ASI eksklusif, karena adanya edukasi yang harusnya diberikan oleh kader posyandu mengenai berbagai macam topik kesehatan ibu dan anak salah satunya adalah ASI eklsusif ${ }^{10,14}$.

Kader posyandu adalah sebagian masyarakat yang bersedia, mampu dan memiliki waktu atau komitmen untuk menyelenggarakan kegiatan posyandu secara sukarela, mau untuk diberikan pendidikan dan pelatihan untuk ikut andil pada masyarakat dalam kegiatan penyelenggaraan kegiatan posyandu ${ }^{15}$. Peran kader posyandu diantaranya adalah pemberi solusi, pendorong proses perubahan pada masyarakat menjadi lebih baik dan sebagai penghubung atau linker ${ }^{16,17}$ dan jika kader posyandu aktif maka kegiatan posyandu menjadi aktif pula18,19, peran kader dalam penyelenggaraan posyandu yang lain adalah sebagai pemberi informasi terutama informasi kesehatan dan sebagai penggerak masyarakat untuk melakukan kunjungan ke posyandu sehingga dapat tercapainya kesuksesan posyandu20,21.

Salah satu indikator yang ditetapkan pada Rencana Strategis Kementerian Kesehatan Tahun 20102014 adalah Kegiatan penimbangan balita yang ada di posyandu $(D / S)^{12,16}$. Partisipasi masyarakat pada kegiatan posyandu juga dapat dijadikan gambaran dan dapat digunakan sebagai deteksi dini masalah jika terjadi masalah kesehatan pada masyarakat terutama balita ${ }^{18}$. Kegiatan posyandu juga peserta posyandu terutama ibu balita seharusnya mendapatkan informasi seputar kesehatan ${ }^{11}$. Tujuan dari penelitian ini adalah mengetahui hubungan antara keaktifan kader dan 
partisipasi ibu dengan cakupan ASI eksklusif pada posyandu yang berada pada wilayah kerja puskesmas Waru Sidoarjo. Penelitian ini dilakukan pada daerah Waru Sidoarjo dikarenakan pada puskesmas Waru memiliki angka cakupan ASI eksklusif yang paling rendah pada tahun 2017 dibanding dengan wilayah lain.

\section{METODE}

Penelitian analitik inferensial dengan desain cross sectional, dilakukan pada posyandu yang berada pada wilayah kerja puskesmas Waru - Sidoarjo dilakukan bulan Juli-September 2018. Populasi adalah semua posyandu yang berada pada wilayah kerja puskesmas Waru Sidoarjo yaitu 102 posyandu yang terdiri dari 3 posyandu Pratama, 27 posyandu Madya, 71 posyandu purnama dan 1 posyandu mandiri. Penentuan besar sample menggunakan metode stratified random sampling sehingga didapatkan jumlah sampel sebanyak 51 posyandu dengan proporsi sehingga didapatkan sampel 34 posyandu pratama dan 17 posyandu madya.

Variabel yang diamati adalah cakupan ASI eksklusif, pelaksanaan kegiatan posyandu, tingkat keaktifan kader dan partisipasi ibu balita, diperoleh dengan pengumpulan data sekunder yang diperoleh dari bidan penganggung jawab kegiatan posyandu dan Focus Group Discussion (FGD) yang dilakukan kepada ibu balita atau peserta posyandu sebagai penguat hasil penelitian. Data sekunder yang dikumpulkan diantaranya adalah kegiatan posyandu (rutin atau tidak rutin, keaktifan kader yang dinilai dari hari kehadiran kader pertahun dengan kategori kurang dari sepuluh kali dalam setahun dianggap tidak rutin dan partisipasi ibu balita dalam kegiatan posyandu (D/S) dengan kategori memenuhi atau belum memehui target sebesar $87 \%$. Untuk memperkuat hasil dilakukan FGD pada 5 posyandu yang dipilih secara acak. Peserta FGD terdiri dari 6-8 ibu yang memiliki anak dengan usia kurang dari dua tahun, hal-hal yang akan di diskusikan adalah pemberian ASI eksklusif, kegiatan posyandu apakah berjalan secara rutin, keaktifan kader, pemberian edukasi oleh kader dan kedatangan atau partisipasi ibu pada kegiatan posyandu. Data yang sudang didapatkan pada penelitian ini dianalisis menggunakan software SPSS 21.0 For Windows. Uji normalitas kemudian dilakukan pada semua variabel yang di teliti. Hubungan antar variabel yang diteliti diuji dengan spearman test dengan signifikansi $5 \%$. Pengolahan hasil FGD dengan melihat hasil diskusi dari ibu balita dan menganalisa jawaban atau hasil FGD terbanyak dari kelima posyandu yang dilakukan FGD. Penelitian ini telah mendapatan persetujuan etik dari Komisi Etik Fakultas Kesehatan Masyarakat Universitas Airlangga Surabaya dengan Nomor 501 pada tanggal 27 Agustus 2018.

\section{HASIL DAN PEMBAHASAN}

Nilai cakupan ASI eksklusif pada Posyandu yang berada di wilayah kerja Puskesmas Waru Sidoarjo menunjukan belum ada Posyandu yang memenuhi target untuk cakupan ASI eksklusif yaitu sebesar $80 \%$. $15.69 \%$ kegiatan posyandu tidak berjalan secara rutin sisanya berjalan secara rutin setiap satu bulan sekali, semestinya penyelenggaraan Posyandu berjalan sekurang-kurangnya satu kali dalam satu bulan, bahkan jika dirasa perlu maka dapat dilakukan kegiatan posyandu lebih dari satu kali namun dengan kesepakatan bersama12. Semua kader posyandu yang termasuk dalam wilayah kerja puskesmas Waru termasuk dalam kategori kader aktif. Sebagian besar Posyandu yang berada di wilayah kerja puskesmas Waru memiliki nilai cakupan $\mathrm{D} / \mathrm{S}$ dengan kategori belum memenuhi target yaitu $44(86,27 \%)$, cakupan $\mathrm{D} / \mathrm{S}$ yang memenuhi target sebesar $7(13,73 \%)$.

Tabel 1. Cakupan ASI eksklusif, pelaksanaan kegiatan posyandu, tingkat keaktifan kader, partisipasi ibu balita

\begin{tabular}{lcc}
\multicolumn{1}{c}{ Variable } & $\mathbf{n}$ & $\%$ \\
\hline \multicolumn{1}{c}{ Cakupan ASI eksklusif } & & \\
$\quad$ Sesuai target $(>80 \%)$ & 0 & 0 \\
Tidak sesuai $(<80 \%)$ & 51 & 100 \\
\hline Total & 51 & 100 \\
\hline Pelaksanaan posyandu & & \\
$\quad$ Rutin & 43 & 84,31 \\
$\quad$ Tidak rutin & 8 & 15.69 \\
\hline Total & 51 & 100 \\
\hline Keaktifan kader & & \\
$\quad$ Aktif & 51 & 100 \\
$\quad$ Tidak aktif & 0 & 0 \\
\hline Total & 51 & 100 \\
\hline Partisipasi ibu (D/S) & & \\
$\quad$ Sesuai target (>87\%) & 7 & 13,73 \\
$\quad$ Tidak sesuai $(<87 \%)$ & 44 & 86,27 \\
\hline Total & 51 & 100 \\
\hline
\end{tabular}

Tabel 2. Hasil Uji hubungan ASI ekslusif

\begin{tabular}{lc}
\hline \multicolumn{1}{c}{ Variable } & p value \\
\hline Pelaksanaan kegiatan posyandu & 0,004 \\
Keaktifan kader & 0,691 \\
Partisipasi ibu (D/S) & 0,077 \\
\hline Keterangan: Signifikansi berdasarkan uji & spearman
\end{tabular}

Keterangan: Signifikansi berdasarkan uji spearman dengan $p$ value $<0,05$

Untuk memperkuat hasil dilakukan FGD, pertanyaan pembuka pada sesi FGD adalah definisi ASI eksklusif menurut ibu balita peserta FGD. Dari kelima Posyandu peserta memiliki jawaban yang berbeda. Namun sebagian besar peserta FGD sudah menjawab dengan benar yaitu memberikan ASI sampai umur balita enam bulan yang di tuliskan dalam kutipan berikut :

"Bayi diberi ASI saja sampai usia enam bulan $\operatorname{mbak}^{\prime \prime}(\mathrm{YY}, 27)$

Namun beberapa peserta FGD ada yang kurang tepat dalam menjawab definisi ASI eksklusif yang tertulis dalam kutipan berikut :

"Menyusui bayi sampai dua tahun mbak" (IK, 33)

Pertanyaan berikutnya adalah penting atau tidaknya ASI untuk bayi atau anak dengan menyebutkan alasan mengapa penting atau tidaknya ASI untuk anak atau bayi tersebut. Semua ibu balita pada lima Posyandu 
kompak menjawab ASI penting dengan berbagai alasan yang dituliskan dalam kutipan berikut :

"Ya penting mbak, ASI kan buat daya tahan tubuh anak, biar anak ndak sakitsakitan." (ST, 30)

Ibu balita lain menjawab dengan lantang bahwa ASI eksklusif itu penting namun disertai dengan alasan yang berbeda yang dituliskan dalam kutipan berikut:

"Penting mbak ASI kan kandungan vitamin dan mineralnya banyak jadi ya penting kan mbak?" (DW, 26)

Salah satu ibu balita menjawab ASI eksklusif penting dikarenakan bidan yang memberitahu, yang dituliskan dalam kutipan berikut:

"Kata bidan ASI itu penting mbak, makanan yang paling baik buat bayi jadi ya penting mbak." (SA, 32)

Selain alasan kandungan asi, kesehatan payudara juga menjadi alasan untuk ibu balita mengapa ASI itu penting, yang ditulis dalam kutipan berikut:

"Kalo ndak nyusuin payudara saya sakit'e mbak jadi ya penting, penting untuk kesehatan ibu dan bayinya hehehe." (TM, 27)

Dari hasil FGD ditemukan beberapa ibu balita yang memiliki pemahaman kurang mengenai ASI eksklusif hal tersebut sejalan dengan penelitian Septiani, ASI eksklusif lebih banyak pada kelompok ibu dengan pengetahuan baik $(72,8 \%)$ dibandingkan ibu dengan pengetahuan kurang $(20,6 \%)^{22}$. Selain pengetahuan ibu bekerja juga menjadi salah satu faktor pemberian ASI eksklusif, dari hasil FGD salah satu alasan ibu tidak memberikan ASI adalah karena ibu bekerja hal tersebut sejalan dengan penelitian Bahriyah, et al, bahwa terdapat hubungan antara ibu bekerja dengan pemberian ASI eksklusif ${ }^{23}$.

Pertanyaan selanjutnya adalah apakah ibu melakukan ASI eksklusif atau berencana melakukan ASI eksklusif jika usia bayi sekarang kurang dari enam bulan, dan jika tidak disebutkan dengan alasan. melaksanakan ASI eksklusif dikarenakan terkait bebagai permasalahan dan alasan. Salah satu permasalahan yang dialami ibu balita adalah ibu yang bekerja, yang dituliskan dalam kutipan berikut :

"Pingin sih mbak ASI eksklusif tapi tak kasih susu formula mbak, soale saya kerja jadi gabisa nyusuin." (TS, 33)

Selain alasan ibu yang berkerja alasan lain adalah pemberian susu formula pada anak dikarenakan ibu yang tidak tega melihat anak rewel dan merasa ASI nya tidak cukup, yang dituliskan dalam kutipan berikut :
"Saya juga kasi susu formula soalnya anak ku rewel mbak kayae laper gitu lo. takut ASI ku gak cukup juga " (MY, 26)

Pemberian susu formula juga diberikan pada anak oleh ibu balita lain pada anak namun dengan alasan yang berbeda yaitu pemberian makanan tambahan yang diberikan oleh nenek dari anak berupa susu formula, yang tertulis dalam kutipan berikut :

"Anak ku juga mbak pake susu formula, tapi bukan saya yang kasi tapi nenek nya katanya anaku kurus dikasi susu biar gemuk." (JM,30)

Permasalahan lain yang di katakan oleh ibu balita adalah ASI dari ibu balita yang tidak keluar, yang dituliskan dalam kutipan berikut :

"ASI saya ndak keluar mbak jadi saya gabisa nyusuin, kasian juga anak nya, soalnya kan ASI saya ga keluar." ( TS, 33)

Selain ibu yang bekerja pemberian susu formula juga menjadi salah satu faktor pemberian ASI eksklusif, dari hasil FGD didapatkan hasil bahwa ibu memberikan susu formula sebelum usia 6 bulan dikarenakan keluhan ASI yang keluar sedikit, dituliskan dalam kutipan berikut

"ASI saya ndak keluar mbak jadi saya ga bisa nyusuin, kasian juga anak saya nya, soalnya kan ASI saya ga keluar" (YY, 27)

Hal serupa sejalan dengan penelitian Setyorini, et al, yaitu pengetahuan berhubungan dengan pemberian ASI eksklusif pada anak. ${ }^{24}$

Topik selanjutnya adalah mengenai keaktifan kader menurut peserta posyandu, semua peserta FGD menjawab bahwa kegiatan Posyandu berlangsung secara rutin, namun terkadang ibu balita yang berhalangan hadir dengan alasan, yang tertulis dalam kutipan berikut:

"Aktif kok mbak sebulan sekali" (DW,

Dan ditambahkan oleh ibu balita lain juga mengatakan bahwa aktif namun ibu balita terkadang tidak dapat hadir, yang dituliskan dalam kutipan berikut :

"lya aktif kok mba sama, tapi kadang saya berhalangan hadir. Rasanya bu kadernya ndak pernah absen ibunya yang sering absen hehehe" (YY, 27)

Ibu balita lain mengatakan aktif, yang dituliskan dalam kutipan berikut :

"Aktif mbak ya itu-itu aja bu kadernya yang datang setiap bulan" (MY, 31).

Topik rutinitas kegiatan posyandu yang berjalan secara rutin atau tidak rutin secara tidak langsung 
berhubungan dengan partisipasi ibu balita pada kegiatan posyandu ditemukan beberapa faktor yang mempengaruhi partisipasi ibu balita $(D / S)$. Ibu balita tidak selalu bisa hadir dalam kegiatan Posyandu tersebut, yang tertulis dalam kutipan berikut :

"Ya rutin mbak posyandunya, sebulan sekali cuman kadang saya yang ngga bisa datang gara-gara ada keperluan lain." ( AM, 29)

Alasan lain mengapa ibu balita tidak hadir dalam kegiatan posyandu adalah ibu yang bekerja sehingga tidak dapat menghadiri kegiatan Posyandu, yang dituliskan dalam kutipan berikut :

"Rutin kok mbak tiap bulan tapi kan saya kerja jadi ga bisa nganter, jadi biasanya neneknya yang nganter ke Posyandu. Ini tadi kebetulan saya libur." (RU, 31)

Alasan lain yang menghambat ibu balita datang ke Posyandu adalah anak yang rewel sehingga ibu balita tidak dapat hadir dalam kegiatan Posyandu, yang dituliskan dalam kutipan berikut:

"Rutin mbak tapi ya gitu kadang anak anak tiba-tiba rewel dan nangis jadi saya ga jadi ke Posyandu." (MY, 26)

\section{KESIMPULAN}

Berdasarkan hasil penelitian dari 51 posyandu $83,31 \%$ kegiatan posyandu berjalan secara rutin yaitu setiap bulan sekali sedangkan $15,69 \%$ tidak rutin. Semua kader termasuk dalam kategori aktif, sebagian besar Posyandu memiliki nilai cakupan D/S dengan kategori belum memenuhi target yaitu $44(86,27 \%)$, cakupan D/S yang memenuhi target sebesar 7 (13,73\%). Tidak ditemukan hubungan antara partisipasi ibu balita dan keaktifan kader dengan cakupan ASI eksklusif pada posyandu di wilayah kerja puskesmas Waru Sidoarjo. Ada hubungan antara kerutinan kegiatan posyandu dengan cakupan ASI eksklusif di wilayah kerja puskesmas Waru. Dari hasil FGD didapatkan faktor-faktor yang mempegaruhi cakupan ASI eksklusif adalah sebagai berikut pengetahuan, pemberian susu formula dan ibu yang bekerja, sehingga perlu ditingkatkanya sosialisasi terutama mengenai kiat-kiat sukses ASI eksklusif pada ibu bekerja dan meningkatkan pelaksanaan posyandu yang belum berjalan secara rutin dengan bekerjasama antara masyarakat dan tenaga kesehatan.

\section{ACKNOWLEDGEMENT}

Peneliti mengucapkan terimakasih kepada seluruh responden, Dinas Kesehatan Kabupaten Sidoarjo dan Kepala Puskesmas Waru yang telah mengijinkan melakukan penelitian dan pengambilan data.

\section{REFERENSI}

1. Unicef. Breastfeeding. (2011).
2. Kementrian Kesehatan. Profil Kesehatan Indonesia Tahun 2013. Jakarta: Kementerian Kesehatan RI (2014). doi:351.770.212 Ind P

3. Badan Penelitian dan Pengembangan Kesehatan. Riset Kesehatan Dasar (RISKESDAS) 2007. Lap. Nas. 2007 (2007). doi:1 Desember 2013

4. Dinas Kesehatan Sidoarjo. PROFIL KESEHATAN KABUPATEN SIDOARJO TAHUN 2014. (2015).

5. Dinas Kesehatan Sidoarjo. Laporan Tahunan 2017. (2018).

6. Kurniawan, B. Determinan Keberhasilan Pemberian Air Susu Ibu Eksklusif. J. Kedokt. Brawijaya

(2013). doi:10.1533/9780857099266.1.166

7. Kementrian Kesehatan Republik Indonesia. Sepuluh Manfaat ASI. (2016).

8. Ri, K. K. Peraturan Pemerintah Republik Indonesia No 33 Tahun 2012. Peratur. Pemerintah Republik Indones. No 33 Tahun 2012 (2012). doi:S0167-8140(04)00565-1 [pii]10.1016/j.radonc.2004.12.010

9. Republik Indonesia. Peraturan Pemerintah Republik Indonesia Noor 33 Tahunn 2102 tentang Pemberian Air Susu Ibu Eksklusif. 2012 (2012). doi:10.1016/S0009-2509(01)00413-4

10. Do Paço, A. et al. The role of marketing in the promotion of breastfeeding. J. Med. Mark. (2010). doi:10.1057/jmm.2010.13

11. Susanto, A. Peran Kader Posyandu Sebagai Agen Perubahan Perilaku Pada Ibu Hamil Dalam Upaya Menekan Angka Kematian. 2nd Semin. Nas. IPTEK Terap. 2017 (2017).

12. Kementerian Kesehatan RI. Pedoman Umum Pengelolaan Posyandu. Kementerian Kesehatan RI (2011). doi:362.11.Ind P

13. M Kresno. Pemanfaatan Posyandu di Kelurahan Cipinang Kec. Jatinegara Kodya Jakarta Timur. (FKM Universitas Indonesia, 2008).

14. Retnowati, Y., Noviani, D. \& Susanti, S. UPAYA PENINGKATAN KEIKUTSERTAAN IBU DALAM KELOMPOK KELAS IBU HAMIL DI WILAYAH PUSKESMAS JUATA LAUT KOTA TARAKAN. JPMB (Jurnal Pengabdi. Masy. Borneo) (2017).

15. Kementrian Kesehatan RI. Ayo ke Posyandu Setiap Bulan. Kementrian Kesehatan Ri Pusat Promosi Kesehatan (2012). doi:10.1159/000317898

16. Djuhaeni, H., Gondodiputro, S. \& Suparman, R. Motivasi Kader Meningkatkan Keberhasilan Kegiatan Posyandu. Maj. Kedokt. Bandung (2010). doi:10.15395/mkb.v42n4.26

17. Miskin, S., Rompas, S. \& ISmanto, A. Y. Hubungan pengetahuan ibu dan peran kader dengan kunjugan balita di posyandu wilayah kerja Puskesmas Pineleng. E-journal Keperawatan (2016).

18. Akbar, M. A., Kandarina, B. I. \& Alit Gunawan, I. M. Studi Ketidakaktifan Kader Posyandu di Wilayah Kerja Puskesmas Paramasan, Banjar, Kalimantan Selatan. J. Gizi dan Diet. Indones. (Indonesian J. Nutr. Diet. (2016). doi:10.21927/ijnd.2015.3(1).60-67 
19. Suhat \& Hasanah, R. Faktor-Faktor yang Berhubungan dengan Keaktifan Kader dalam Kegiatan Posyandu (Studi Kasus di Puskesmas Palasari Kabupaten Subang). J. Kesehat. Masy. (2014). doi:ISSN 1858-1196

20. Sholihah, N. \& Kusumadewi, S. Sistem Informasi Posyandu Kesehatan Ibu dan Anak. in Prosiding SNATIF (2015).

21. Kader, P., Dalam, P., Dektesi, U. \& Kesehatan, D. Kata Kunci: kegiatan posyandu, peran aktif kader, kegiatan terintegrasi . PENDAHULUAN. J. Pengabdi. pada Masy. (2014).
22. Septiani, H., Budi, A. \& Karbito. Faktor-Faktor yang Berhubungan dengan Pemberian ASI Eksklusif Oleh Ibu Menyusui yang Bekerja Sebagai Tenaga Kesehatan. J. Ilmu Kesehat. 2, 159-174 (2017).

23. Bahriyah, F., Outri, M. \& Jaelani, A. K. Hubungan Pekerjaan Ibu Terhadap Pemberian ASI Eklsusif pada Bayi. J. Endur. 2, 113-118 (2017).

24. Setyorini, R. N., Widjanarko, B. \& Suguhantono, A. Faktor-Faktor yang Mempengaruhi Perilaku Pemberian Air Susu Ibu(ASI) Ekslusif di Wilayah Kerja Puskesmas Pegandan Kota Semarang. J. Kesehat. Masy. 5, 620-628 (2107). 